\title{
A Systematic Review of the Effects of Hyperoxia in Acutely Ill Patients: Should We Aim for Less?
}

\author{
R. Stolmeijer $\mathbb{D}^{1}{ }^{1}$ H. R. Bouma, ${ }^{2,3}$ J. G. Zijlstra, ${ }^{4}$ A. M. Drost-de Klerck, ${ }^{5}$ \\ J. C. ter Maaten, ${ }^{3,5}$ and J. J. M. Ligtenberg ${ }^{3,5}$ \\ ${ }^{1}$ Department of Emergency Medicine, Medical Center Leeuwarden, Leeuwarden, Netherlands \\ ${ }^{2}$ Department of Clinical Pharmacy \& Pharmacology, University Medical Center Groningen, University of Groningen, \\ Groningen, Netherlands \\ ${ }^{3}$ Department of Internal Medicine, University Medical Center Groningen, University of Groningen, Groningen, Netherlands \\ ${ }^{4}$ Department of Critical Care, University Medical Center Groningen, University of Groningen, Groningen, Netherlands \\ ${ }^{5}$ Department of Emergency Medicine, University Medical Center Groningen, University of Groningen, Groningen, Netherlands
}

Correspondence should be addressed to R. Stolmeijer; renate.stolmeijer@znb.nl

Received 17 July 2017; Revised 4 January 2018; Accepted 12 April 2018; Published 14 May 2018

Academic Editor: Zongbao K. Zhao

Copyright $(2018$ R. Stolmeijer et al. This is an open access article distributed under the Creative Commons Attribution License, which permits unrestricted use, distribution, and reproduction in any medium, provided the original work is properly cited.

Introduction. Despite widespread and liberal use of oxygen supplementation, guidelines about rational use of oxygen are scarce. Recent data demonstrates that current protocols lead to hyperoxemia in the majority of the patients and most health care professionals are not aware of the negative effects of hyperoxemia. Method. To investigate the effects of hyperoxemia in acutely ill patients on clinically relevant outcomes, such as neurological and functional status as well as mortality, we performed a literature review using Medline (PubMed) and Embase. We used the following terms: hyperoxemia OR hyperoxemia OR ["oxygen inhalation therapy" AND (mortality OR death OR outcome OR survival)] OR [oxygen AND (mortality OR death OR outcome OR survival)]. Original studies about the clinical effects of hyperoxemia in adult patients suffering from acute or emergency illnesses were included. Results. 37 articles were included, of which 31 could be divided into four large groups: cardiac arrest, traumatic brain injury (TBI), stroke, and sepsis. Although a single study demonstrated a transient protective effect of hyperoxemia after TBI, other studies revealed higher mortality rates after cardiac arrest, stroke, and TBI treated with oxygen supplementation leading to hyperoxemia. Approximately half of the studies showed no association between hyperoxemia and clinically relevant outcomes. Conclusion. Liberal oxygen therapy leads to hyperoxemia in a majority of patients and hyperoxemia may negatively affect survival after acute illness. As a clinical consequence, aiming for normoxemia may limit negative effects of hyperoxemia in patients with acute illness.

\section{Introduction}

Oxygen is a vital element and toxicity may not be immediately obvious. Moreover, impaired oxygen delivery in critically ill patients is associated with increased mortality. As a consequence, reassuring oxygen delivery has become a cornerstone of many resuscitation protocols and liberal use of supplemental oxygen is common [1]. The negative effects of too much oxygen are less clear and many health care professionals are unaware of the possible damage hyperoxemia can cause [2]. In contrast to guidelines describing rational use of drugs, similar guidelines for optimal use of oxygen are scarce. However, the British Thoracic Society (BTS) guideline of 2008 [3] does recommend to aim for (near) normal oxygen saturation for all acutely ill patients and to preclude hyperoxemia. Titration of oxygen therapy appears to be feasible, both in the emergency department (ED) and in the intensive care unit (ICU) $[4,5]$. In critical situations, however, oxygen supplementation is generally started without checking for hypoxemia. It is also often not titrated to lower level of oxygen supplementation, despite oxygen saturation readings of (close to) $100 \%$ or high partial oxygen pressures $\left(\mathrm{PaO}_{2}\right)$ [6]. Importantly, recent studies have revealed that not only hypoxemia but also hyperoxemia is associated with increased mortality, although data are inconsistent [1,7-9].

Harmful effects of hyperoxemia may be due to various mechanisms, ranging from vasoconstriction and microvascular blood flow heterogeneity to increased formation of 
reactive oxygen species (ROS) $[1,10]$. Oxygen is a critical element to fuel oxidative phosphorylation for the generation of ATP by mitochondria. Since ATP is mainly produced by means of oxidative phosphorylation, hypoxemia may impair the production of ATP and thereby lead to cellular ATP depletion. On the other hand, hyperoxemia may also lead to mitochondrial dysfunction and depletion of cellular ATP levels. Mitochondria are the major source of ROS, which are formed by reduction of oxygen in the electron transport chain (ETC) [11]. Oxidative damage to the ETC-complexes and inhibition of the citric acid cycle by ROS impedes mitochondrial ATP production, which may impair (active) ion transport and thereby leads to loss of cellular homeostasis [12, 13]. Dysfunction of the $\mathrm{Na}^{+} / \mathrm{K}^{+}$-ATPase can initiate cell membrane depolarization and trigger influx of calcium into the cell through voltage-gated channels [14], which subsequently leads to calcium influx into mitochondria. Although high levels of calcium in the mitochondrial matrix initially increase respiratory rate and ATP production [15], a prolonged rise in calcium within mitochondria induces release of cytochrome $c$ and subsequent activation of apoptotic pathways [16]. Taken together, although hypoxemia may impair the generation of ATP, hyperoxemia can also lead to depletion of cellular ATP levels. This is why the standard procedure to supply extra oxygen may lead to mitochondrial damage by increasing the formation of ROS [17]. Moreover, hyperoxemia can result in peripheral vasoconstriction, coronary vasoconstriction, and a decrease in cardiac output [18]. Thus both molecular and physiological effects of (high levels of) oxygen may counteract the positive effects of oxygen supplementation.

Recently, we performed a prospective study in 83 spontaneously breathing patients in the ED to evaluate the effect of conservative oxygen supplementation on blood oxygenation in sepsis. We demonstrated that reducing the inspired oxygen fraction $\left(\mathrm{FiO}_{2}\right)$ from $0.6-0.8$ to 0.4 precludes hypoxemia $(\mathrm{PaO} 2<9.5 \mathrm{kPa}, 9.4 \mathrm{kPa})$ in $93 \%$ of the patients, while $64 \%$ are still hyperoxemic $(\mathrm{PaO} 2>13.5 \mathrm{kPa}, 13.4 \mathrm{kPa})$ [19]. So even lower levels of oxygen supplementation than prescribed lead to hyperoxemia in the majority of patients. Oxygen is a vital and potentially life-saving element in emergency care, which has led to widespread and liberal oxygen supplementation. But it is important to realize that hyperoxemia is associated with increased mortality and unfavorable outcome, such as more neurological impairment and Acute Respiratory Distress Syndrome (ARDS). Decisions about the initiation and discontinuation of oxygen supplementation in acutely ill patients are made in the ED. However, the optimal and nontoxic level of oxygen supplementation in acutely ill patients is not clear. To this end, we performed a systematic review to assess the association between hyperoxemia in acutely ill patients in the ED and outcome in terms of increased morbidity and mortality.

\section{Methods}

2.1. Search Strategy. We performed a systematic review and searched in databases Medline (PubMed) and Embase on the following terms: hyperoxemia OR hyperoxemia OR ["oxygen inhalation therapy" AND (mortality OR death OR outcome
OR survival)] OR [oxygen AND (mortality OR death OR outcome OR survival)]. We searched for studies performed in humans, with full text in English or Dutch available (since these are the languages we are able to read) and that are published in the last 10 years. This 10 -year limitation was chosen because of the new insights into hyperoxia. All abstracts were read (TS); if the abstract met an exclusion criterion, the corresponding article was ruled out. This was confirmed by another author (JL). Of the remaining articles, the entire text was read (TS, JL). Of the articles that were included in this way, reference lists were checked for additional relevant publications, which could also be included if they agreed with inclusion and exclusion criteria. This resulted in 8 more suitable articles for inclusion (Figure 1).

2.2. Inclusion and Exclusion Criteria. Original studies about the clinical effects of hyperoxemia in adult patients suffering from acute or emergency illnesses were included. Thereby, articles not based on original data (e.g., reviews and comments on previous articles of expert opinion) were not included in the review. We excluded articles (1) not concerning acute conditions and (2) not including clinically relevant effects (e.g., effects on cell level). Most articles could be ruled out by reading the title and abstract, for example, studies performed after birth in neonates, in healthy volunteers, or in the diving industry. Also papers in patients with chronic conditions and about use of hyperbaric oxygen therapy were excluded (Figure 1).

2.3. Data Extraction and Analysis. The entire text of all included articles was read and its study design, sample size, definition of hyperoxemia, condition of the patients included, the location of the study, and its main conclusions were summarized in a tabular fashion. Thereby a comprehensive data summary of all included articles was made, which allowed for careful analysis and a comprehensive review of the literature. Differences in study design, heterogeneity, and the different definitions of hyperoxemia and primary outcomes employed in the identified studies lead to a relatively high risk of bias, as assessed using the Cochrane Collaboration's tool. The profound risk of bias hampers performing a meta-analysis. We did not confirm with the authors of the articles that we used. No review protocol exists.

\section{Results}

Our literature search identified 35 manuscripts describing the association between hyperoxemia and clinically relevant outcomes in acutely ill patients. The most important outcomes are mortality, in-hospital mortality, survival, neurological outcome, and organ function. Of the 35 articles, 31 could be divided into four large groups: cardiac arrest, stroke, traumatic brain injury (TBI), and sepsis (Tables 1, 2, and 3). These studies are comprised of four randomized controlled trials (RCT), nine prospective observational studies, and 24 retrospective observational studies. Three other studies were performed in ventilated patients in the ICU, of which 1 study was a RCT. There was one article about patients with 


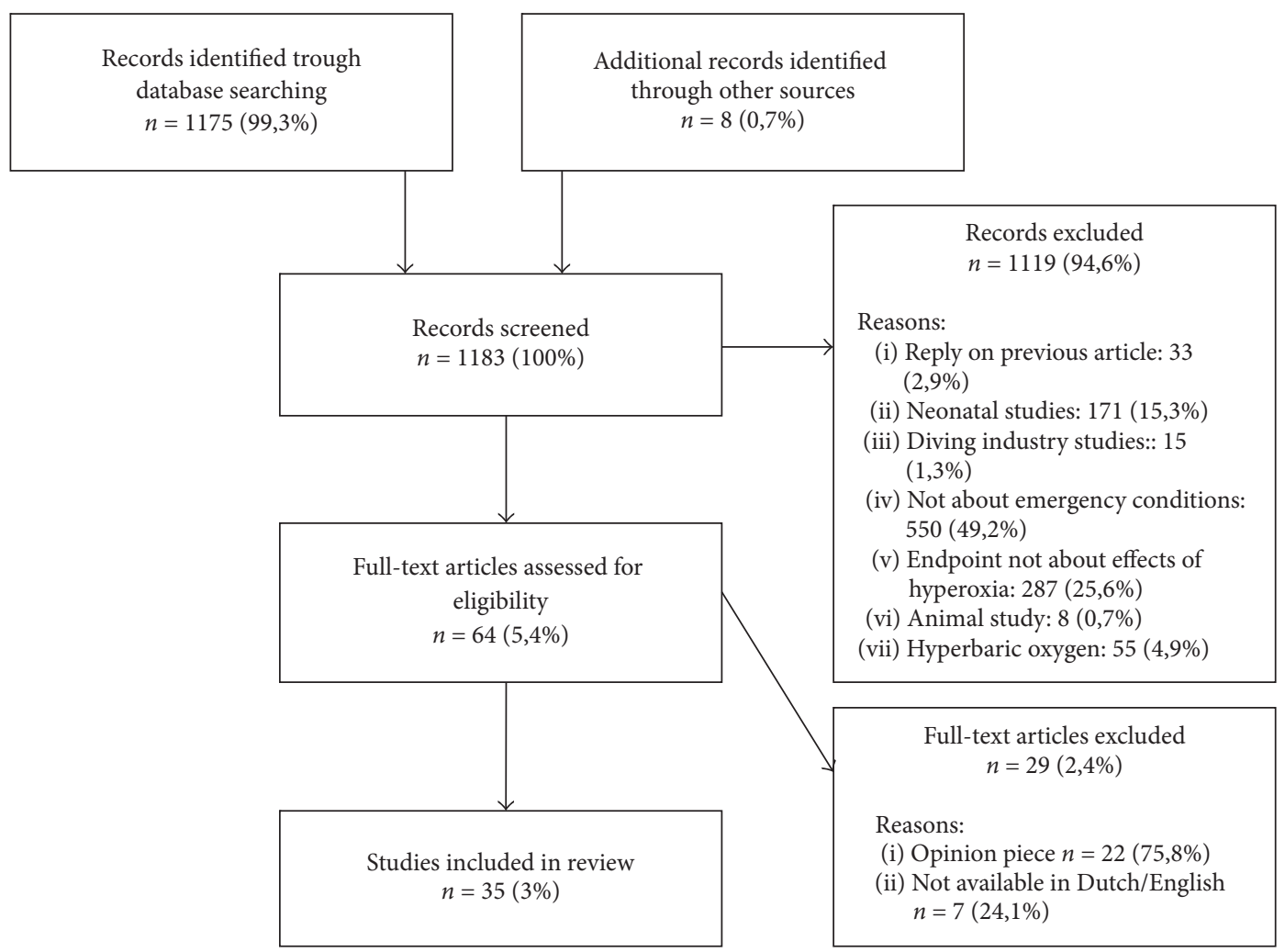

FIGURE 1: Search results.

a ST-elevated myocardial infarction (STEMI). This article will be discussed first.

Ranchord et al. found no benefit or harm from highconcentration oxygen therapy versus oxygen therapy titrated to normoxia in patients with a STEMI 6 hours after presentation on mortality or infarct size measured by troponin levels [20]. This study was a randomized study performed in 136 patients. Unfortunately the authors do not mention the achieved oxygen values in both groups.

3.1. ICU Patients. In one large single-center RCT among $480 \mathrm{ICU}$ patients [50], subjects were randomized either to conservative oxygen supplementation $\left(\mathrm{PaO}_{2} 70-100 \mathrm{mmHg}\right.$ or oxygen saturations 94-98\%) or to conventional oxygen supplementation $\left(\mathrm{PaO}_{2} 100-150 \mathrm{mmHg}\right.$ or oxygen saturations $97-100 \%)$. Patients in the conservative group had lower mortality rates, despite early termination of the study due to lower than expected inclusion rates. Eastwood et al. (2012) performed a retrospective cohort study in 152.680 mechanically ventilated patients in 150 ICUs [7]; 49.8\% had hyperoxia $\left(\mathrm{PaO}_{2}>16 \mathrm{kPa}\right)$. An association was found between hypoxia and increased in-hospital mortality, but not between hyperoxia in the first 24 hours and mortality. Another retrospective cohort study performed in mechanically ventilated ICU patients did show an increase in mortality in case of hyperoxia and also in case of hypoxia [9]. In the three ICU studies mentioned in this section, patients formed a heterogeneous group, since they were suffering from all types of diseases.
3.2. Cardiac Arrest. Thirteen studies evaluated the potential negative effects of hyperoxemia on neurological outcome and mortality in patients after cardiac arrest, as summarized in Table 1. Hyperoxemia during out-of-hospital cardiopulmonary resuscitation (CPR), measured by point-ofcare analysis in the emergency response car, was associated with increased hospital admission rates, as demonstrated in a retrospective cohort study of 1015 patients. No difference in neurologically intact survival was found related to the oxygen concentration, however [21]. Furthermore, the occurrence of hyperoxemia during the first 24 hours of ICU stay in survivors of cardiac arrest is not associated with poorer neurological outcome or increased mortality as compared to normoxemia, as demonstrated in a prospective observational cohort study including 409 patients with 12-month follow-up [22]. Similar to this, no association between the occurrence of hyperoxemia during the first 24 hours after cardiac arrest and inhospital mortality could be demonstrated in a retrospective cohort study in 584 patients after out-of-hospital cardiac arrest (OHCA) due to ventricular fibrillation (VF) [23], in a retrospective cohort study in 5,258 ICU patients after OHCA [24] and in a larger retrospective cohort study comprising 12,108 patients after cardiac arrest [25]. Hence, different prospective and retrospective observational cohort studies were not able to reveal an association between hyperoxemia during CPR or the first 24 hours after cardiac arrest and poor outcome.

In contrast to these findings, one retrospective cohort study found that early hyperoxemia (during the first 60 
TABLE 1: Association between hyperoxemia and clinically relevant outcomes after myocardial infarction and cardiac arrest.

\begin{tabular}{|c|c|c|c|c|c|c|}
\hline Reference & Study design & $\begin{array}{l}\text { Sample } \\
\text { size }\end{array}$ & $\begin{array}{l}\text { Hyperoxemia } \\
\text { definition }\end{array}$ & Condition & Location & Conclusion \\
\hline [20], Ranchordet al. & RCT & 136 & $6 \mathrm{~L} \mathrm{O}_{2} / \mathrm{min}$ & STEMI & - & $\begin{array}{c}\text { High- } \mathrm{O}_{2} \text { therapy had no effect on } \\
\text { mortality or infarct size }\end{array}$ \\
\hline [21], Spindelboeck et al. & $\begin{array}{c}\text { Retrospective } \\
\text { cohort }\end{array}$ & 1015 & $\mathrm{PaO}_{2}>40.0 \mathrm{kPa}$ & Cardiac arrest & Pre-hospital & $\begin{array}{c}\text { Higher hospital admission rates when } \\
\text { during CPR }\end{array}$ \\
\hline [22], Vaahersalo et al. & $\begin{array}{l}\text { Prospective } \\
\text { cohort }\end{array}$ & 409 & $\mathrm{PaO}_{2}>40.0 \mathrm{kPa}$ & Cardiac arrest & ICU & $\begin{array}{l}\text { No association with different } 12 \\
\text { month outcome }\end{array}$ \\
\hline [23], Ihle et al. & $\begin{array}{c}\text { Retrospective } \\
\text { cohort }\end{array}$ & 584 & $\mathrm{PaO}_{2}>40.0 \mathrm{kPa}$ & Cardiac arrest & ICU & $\begin{array}{l}\text { No association with in-hospital } \\
\text { mortality }\end{array}$ \\
\hline [24], Helmerhorst et al. & $\begin{array}{c}\text { Retrospective } \\
\text { cohort }\end{array}$ & 5258 & $\mathrm{PaO}_{2}>39.9 \mathrm{kPa}$ & Cardiac arrest & ICU & $\begin{array}{l}\text { Hyperoxia not associated with higher } \\
\text { mortality rates }\end{array}$ \\
\hline [25], Bellomo et al. & $\begin{array}{c}\text { Retrospective } \\
\text { cohort }\end{array}$ & 12,108 & $\mathrm{PaO}_{2}>40.0 \mathrm{kPa}$ & Cardiac arrest & ICU & No association with mortality \\
\hline [26], Chirst et al. & $\begin{array}{l}\text { Retrospective } \\
\text { cohort }\end{array}$ & 134 & - & Cardiac arrest & - & $\begin{array}{l}\text { Hyperoxia in the first } 60 \text { minutes after } \\
\text { return of circulation is associated with } \\
\text { better survival rates }\end{array}$ \\
\hline [27], Lee et al. & $\begin{array}{l}\text { Retrospective } \\
\text { cohort }\end{array}$ & 213 & - & Cardiac arrest & - & $\begin{array}{c}\text { Hypocarbia associated with } \\
\text { in-hospital mortality. Hypoxemia and } \\
\text { hyperoxemia associated with poor } \\
\text { neurological outcome. }\end{array}$ \\
\hline [28], Kilgannon et al. & $\begin{array}{c}\text { Retrospective } \\
\text { cohort }\end{array}$ & 6,326 & $\mathrm{PaO}_{2}>40.0 \mathrm{kPa}$ & Cardiac arrest & ICU & $\begin{array}{l}\text { Higher mortality rates, even when } \\
\text { compared to hypoxemia }\end{array}$ \\
\hline [29], Elmer et al. & $\begin{array}{l}\text { Retrospective } \\
\text { analysis of } \\
\text { prospective } \\
\text { registry }\end{array}$ & 184 & $\begin{array}{c}\text { Severe: } \\
\mathrm{PaO}_{2}>40.0 \mathrm{kPa} \\
\text { Moderate/ } \\
\text { probable: } \\
\mathrm{PaO}_{2} \\
13.5-39.9 \mathrm{kPa}\end{array}$ & Cardiac arrest & ICU & $\begin{array}{l}\text { Severe associated with higher } \\
\text { in-hospital mortality. } \\
\text { Moderate/probable was not but was } \\
\text { associated with improved organ } \\
\text { function after } 24 \text { hours. }\end{array}$ \\
\hline [30], Kilgannon et al. & $\begin{array}{c}\text { Retrospective } \\
\text { cohort }\end{array}$ & 4,459 & - & Cardiac arrest & ICU & $\begin{array}{l}\text { Dose-dependent association with } \\
\text { in-hospital mortality }\end{array}$ \\
\hline [31], Janz et al. & $\begin{array}{l}\text { Post-hoc } \\
\text { analysis of } \\
\text { prospective } \\
\text { cohort }\end{array}$ & 170 & - & Cardiac arrest & $\begin{array}{l}\text { Cardiovascular } \\
\text { care unit }\end{array}$ & $\begin{array}{l}\text { Higher in-hospital mortality and poor } \\
\text { neurological status on hospital } \\
\text { discharge in survivors }\end{array}$ \\
\hline [32], Young et al. & RCT & 18 & - & Cardiac arrest & Prehospital & $\begin{array}{c}\text { Study terminated early, because } \\
\text { pre-hospital oxygen titration was not } \\
\text { feasible. }\end{array}$ \\
\hline
\end{tabular}

minutes after return of spontaneously circulation) in patients with OHCA was associated with better survival rates [26]. Yet in another study both hyperoxemia and hypoxemia are associated with poor neurological outcome, although no influence of hyperoxemia on in-hospital mortality was found [27]. And another retrospective cohort study comprising 6,326 patients after cardiac arrest reveals an independent association between hyperoxemia and higher in-hospital mortality rates, as compared to normoxemia and hypoxemia [28]. In particular, severe hyperoxemia, which is defined as $\mathrm{PaO}_{2}>39.9 \mathrm{kPa}$, seems to be independently associated with increased in-hospital mortality [29]. Moreover, a multicenter study including 4,459 patients after cardiac arrest revealed a linear, dose-dependent association between oxygen and inhospital mortality: a $13.3 \mathrm{kPa}$ increase in $\mathrm{PaO}_{2}$ was associated with a $24 \%$ increase in mortality risk [30]. The occurrence of hyperoxemia during postresuscitation care combined with mild hypothermia is independently associated poorer neurological outcome at hospital discharge and increased in-hospital mortality, as demonstrated in an observational cohort study comprising 170 patients. As such, survivors (45\%) had a lower maximum $\mathrm{PaO}_{2}(26.4 \mathrm{kPa})$ in the first 24 hours versus nonsurvivors $(55 \% ; 33.9 \mathrm{kPa})$ [31]. So in contrast to the lack of an association between (mild) hyperoxemia during the early stages after cardiac arrest and neurologically intact survival, severe hyperoxemia and hyperoxemia during postresuscitation care seem to be associated with poorer outcome.

Current evidence describing the advantages and drawbacks of hyperoxemia during and after CPR is limited to observational studies. Unfortunately, a randomized multicenter single-blind trial (HOT or NOT, 2014), in which the goal was to assess the prehospital effect of oxygen titration versus standard oxygen therapy after out-of-hospital cardiac 
TABLE 2: Association between hyperoxemia and clinically relevant outcomes after stroke and traumatic brain injury.

\begin{tabular}{|c|c|c|c|c|c|c|}
\hline Reference & Study design & $\begin{array}{l}\text { Sample } \\
\text { size }\end{array}$ & $\begin{array}{c}\text { Hyperoxemia } \\
\text { definition }\end{array}$ & Condition & Location & Conclusion \\
\hline [33], Young et al. & $\begin{array}{c}\text { Retrospective } \\
\text { cohort }\end{array}$ & 2,643 & - & Ischaemic stroke & ICU & No association with mortality. \\
\hline [34], Rincon et al. & $\begin{array}{l}\text { Retrospective } \\
\text { cohort }\end{array}$ & 2,894 & $\mathrm{PaO}_{2}>40.0 \mathrm{kPa}$ & $\begin{array}{l}\text { Ischaemic } \\
\text { stroke, } \\
\text { subarachnoid or } \\
\text { intracerebral } \\
\text { hemorrhage }\end{array}$ & ICU & $\begin{array}{l}\text { Associated with higher in-hospital } \\
\text { mortality, also when compared to } \\
\text { hypoxemia. }\end{array}$ \\
\hline [35], Lång et al. & $\begin{array}{l}\text { Retrospective } \\
\text { cohort }\end{array}$ & 432 & - & $\begin{array}{l}\text { Subarachnoidal } \\
\text { hemorrhage }\end{array}$ & ICU & $\begin{array}{c}\text { Unfavorable outcome associated } \\
\text { with higher } \mathrm{PaO}_{2} \text {, but higher } \mathrm{PaO}_{2} \\
\text { levels after multivariate analysis not } \\
\text { associated with unfavorable } \\
\text { outcome or mortality }\end{array}$ \\
\hline [36], Singhal et al. & $\begin{array}{l}\text { Randomized } \\
\text { pilot study, } \\
\text { partially } \\
\text { blinded }\end{array}$ & 16 & $\begin{array}{c}\mathrm{O}_{2} 45 \mathrm{~L} / \mathrm{min}, 8 \\
\text { hours }\end{array}$ & Ischaemic stroke & - & $\begin{array}{c}\text { Transient improvement of clinical } \\
\text { deficits and MRI abnormalities after } \\
24 \text { hours }\end{array}$ \\
\hline [37], Padma et al. & $\begin{array}{l}\text { Randomized } \\
\text { pilot study, } \\
\text { partially } \\
\text { blinded } \\
\end{array}$ & 40 & $\begin{array}{c}\mathrm{O}_{2} 10 \mathrm{~L} / \mathrm{min}, 12 \\
\text { hours }\end{array}$ & Ischaemic stroke & - & $\begin{array}{c}\text { No improvement in functional or } \\
\text { neurological outcome after } 3 \\
\text { months }\end{array}$ \\
\hline [38], Nortje et al. & $\begin{array}{c}\text { Prospective } \\
\text { cohort }\end{array}$ & 11 & $\mathrm{FiO}_{2} 35-50 \%$ & TBI & - & Increases brain tissue oxygenation. \\
\hline [39], Tisdall et al. & $\begin{array}{l}\text { Prospective } \\
\text { cohort }\end{array}$ & 8 & $\mathrm{FiO}_{2} 100 \%$ & TBI & $\begin{array}{l}\text { Neurological } \\
\text { ICU }\end{array}$ & $\begin{array}{c}\text { Increases cerebral aerobic } \\
\text { metabolism. }\end{array}$ \\
\hline [40], Vilalta et al. & $\begin{array}{l}\text { Prospective } \\
\text { cohort }\end{array}$ & 30 & $\mathrm{FiO}_{2} 100 \%$ & TBI & ICU & $\begin{array}{c}\text { Improves brain redox state in } \\
\text { patients with initially elevated brain } \\
\text { lactate levels }\end{array}$ \\
\hline [41], Diringer et al. & $\begin{array}{l}\text { Prospective } \\
\text { cohort }\end{array}$ & 5 & $\mathrm{FiO}_{2} 100 \%$ & TBI & $\begin{array}{l}\text { Neurosurgical } \\
\text { ICU }\end{array}$ & $\begin{array}{l}\text { No improvement on brain } \\
\text { metabolism. }\end{array}$ \\
\hline [42], Puccio et al. & $\begin{array}{c}\text { Prospective } \\
\text { cohort }\end{array}$ & 11 & $\mathrm{FiO}_{2} 100 \%$ & TBI & $\begin{array}{l}\text { Neurotrauma } \\
\text { ICU }\end{array}$ & $\begin{array}{l}\text { Brief periods do not produce } \\
\text { oxidative stress and/or change } \\
\text { antioxidant reserves in } \\
\text { cerebrospinal fluid. }\end{array}$ \\
\hline [43], Davis et al. & $\begin{array}{l}\text { Retrospective } \\
\text { cohort }\end{array}$ & 3,420 & $\mathrm{PaO}_{2}>64.9 \mathrm{kPa}$ & TBI & - & $\begin{array}{l}\text { Independently associated with } \\
\text { increased mortality and decrease in } \\
\text { good outcomes. }\end{array}$ \\
\hline [44], Rincon et al. & $\begin{array}{l}\text { Retrospective } \\
\text { cohort }\end{array}$ & 1,212 & $\mathrm{PaO}_{2}>40.0 \mathrm{kPa}$ & TBI & ICU & $\begin{array}{l}\text { Independently associated with } \\
\text { higher in-hospital mortality. }\end{array}$ \\
\hline [45], Asher et al. & $\begin{array}{c}\text { Retrospective } \\
\text { cohort }\end{array}$ & 193 & $\mathrm{PaO}_{2}>64.8 \mathrm{kPa}$ & TBI & - & Decrease in survival \\
\hline [46], Raj et al. & $\begin{array}{l}\text { Retrospective } \\
\text { cohort }\end{array}$ & 1,116 & $\mathrm{PaO}_{2}>13.3 \mathrm{kPa}$ & TBI & ICU & No effect on 6 month mortality \\
\hline
\end{tabular}

arrest, was terminated early because titration of oxygen in the prehospital period following OHCA appeared to be unfeasible. The authors suggested that it may be more practicable to titrate the dosage of oxygen down immediately after arrival at the ED or elsewhere in hospital [32]. In conclusion, the level of evidence describing the effect of hyperoxemia on clinically relevant outcome after cardiac arrest is low. Outcomes of studies evaluating hyperoxemia after cardiac arrest are unequivocal, although current data suggests an association between (severe) hyperoxemia during postresuscitation care and lower levels of intact neurological survival.
3.3. Stroke. The use of hyperoxemia in acute neurological events is controversial. While some state that it has beneficial effects on the injured brain and should be used as therapy due to its hemodynamic effects, others state that hyperoxemia should be avoided as it may increase neurological damage due to the formation of ROS. We included five studies in patients with stroke (Table 2). The application of hyperoxemia in ventilated patients early after acute ischemic stroke is not associated with poor functional outcome or increased mortality, as revealed in a retrospective study in 2,643 patients [33]. In contrast, a retrospective multicenter study in 2,894 ventilated patients after acute ischemic stroke, subarachnoid 
TABLE 3: Association between hyperoxemia and clinically relevant outcomes in sepsis.

\begin{tabular}{|c|c|c|c|c|c|c|}
\hline Reference & Study design & $\begin{array}{l}\text { Sample } \\
\text { size }\end{array}$ & $\begin{array}{l}\text { Hyperoxemia } \\
\text { definition }\end{array}$ & Condition & Location & Conclusion \\
\hline [19], Stolmeijer et al. & $\begin{array}{l}\text { Prospective } \\
\text { cohort }\end{array}$ & 83 & $\mathrm{PaO}_{2}>13.5 \mathrm{kPa}$ & Sepsis & $\mathrm{ED}$ & $\begin{array}{l}\text { More than } 64 \% \text { of patients were } \\
\text { hyperoxemic with } 10 \mathrm{~L} \mathrm{O}_{2} / \mathrm{min} \text {. No } \\
\text { association with mortality. }\end{array}$ \\
\hline [47], Rossi et al. & $\begin{array}{l}\text { Prospective } \\
\text { cohort }\end{array}$ & 14 & $\mathrm{FiO}_{2} 100 \%$ & Sepsis & ICU & $\begin{array}{c}\text { Decreases oxygen delivery in upper } \\
\text { limbs. }\end{array}$ \\
\hline [48], Pope et al. & $\begin{array}{l}\text { Retrospective } \\
\text { cohort }\end{array}$ & 619 & $\begin{array}{l}\text { Central venous } \\
\text { saturation } \\
\left(\mathrm{ScvO}_{2}\right) \\
90-100 \%\end{array}$ & Sepsis & $\mathrm{ED}$ & Associated with increased mortality. \\
\hline [49], Dahl et al. & $\begin{array}{l}\text { Retrospective } \\
\text { cohort }\end{array}$ & 1,770 & $\mathrm{PaO}_{2}>16.0 \mathrm{kPa}$ & Sepsis & ICU & $\begin{array}{l}\text { No effect on mortality, but } \\
\text { hypoxemia and } \mathrm{FiO}_{2}>60 \% \\
\text { increased mortality. }\end{array}$ \\
\hline
\end{tabular}

hemorrhage (SAH), and intracerebral hemorrhage demonstrated an independent association between hyperoxemia and increased in-hospital mortality. This was $60 \%$ after hyperoxemia and $47 \%$ after normoxemia [34]. The effect of hyperoxemia on neurological outcome was not assessed in this study unfortunately. Another retrospective cohort study in mechanically ventilated patients with a SAH in the ICU showed that patients with unfavorable outcome (Glasgow Coma Score 1-3) had significantly higher $\mathrm{PaO}_{2}$ levels. But in a multivariate regression analysis no association between $\mathrm{PaO}_{2}$ and unfavorable outcome of mortality was found [35]. A small randomized and partially blinded pilot study in which patients were treated with high levels of oxygen supplementation ( $45 \mathrm{~L} / \mathrm{min}$ for 8 hours) or ambient air after acute ischemic stroke revealed a transient improvement of clinical deficits and MRI abnormalities at 24 hours after inclusion. This disappeared at three-month follow-up [36]. In this study the effect of hyperoxemia on mortality was not assessed. Another randomized study where 40 patients with acute ischemic stroke received either high oxygen supplementation (10 L/min for 12 hours) or ambient air was not able to demonstrate an association between high oxygen supplementation and neurological or functional outcome during three-month follow-up [37]. In summary, the association between hyperoxemia after stroke has been described in a very low number of studies, who either describe no effect of hyperoxemia on clinically relevant outcomes or suggest minor transient protective effects of hyperoxemia.

3.4. Traumatic Brain Injury. Hyperoxemia may have protective effects after TBI by improving brain oxygenation and thereby preventing ischemic injury. The application of hyperoxemia after TBI improves brain tissue oxygenation indeed, as demonstrated by cerebral microdialysis, brain tissue oximetry, and oxygen-15 positron emission tomography (PET) in a small study comprising 11 patients with TBI [38]. The use of hyperoxemia not only increases brain oxygen levels, but subsequently also leads to a reduced lactatepyruvate ratio, which suggests an improved preservation of mitochondrial respiration $[39,40]$. Despite an improvement in brain oxygenation and metabolism after TBI, a smaller study comprising five patients with TBI demonstrated no effects on arterial blood pressure, intracranial pressure, and cerebral blood flow when patients were subjected to a $\mathrm{FiO} 2$ of 0.3-0.5 or 1.0 for one hour [41]. Moreover, the use of hyperoxemia in TBI patients is not associated with increased levels of oxidative stress or changes in antioxidant reserves in spinal fluid [42]. Hence, hyperoxemia is associated with improved oxygenation and better mitochondrial respiration after TBI.

The occurrence of hyperoxemia after severe TBI is associated with a decrease in good clinical outcome (such as being able to be discharged home) and higher levels of mortality, as demonstrated in a registry based retrospective cohort comprising 3,420 patients with severe TBI [43]. Similar findings were obtained in a multicenter retrospective registry study among 1,212 mechanically ventilated patients suffering from TBI, where hyperoxemia within 24 hours after admission to the ICU is independently associated with higher in-hospital mortality rates [44]. These findings are in line with a small retrospective cohort study, demonstrating increased mortality among patients with either hypoxemia $\left(\mathrm{PaO}_{2}<33.3 \mathrm{kPa}\right)$ and hyperoxemia $\left(\mathrm{PaO}_{2}>64.8 \mathrm{kPa}\right)$ as compared to normoxemia after TBI [45]. Another relatively large retrospective cohort study, comprising 1,116 patients with TBI, was not able to reveal an association between hyperoxemia (>13.3 $\mathrm{kPa}$ ) and mortality at six-month followup in contrast [46]. In conclusion, although hyperoxemia after TBI improves brain oxygenation and mitochondrial function, the use of hyperoxemia seems to be associated with increased in-hospital mortality.

3.5. Sepsis. In contrast to cardiac arrest, stroke, and TBI, optimizing cellular oxygen delivery may be even more difficult in patients with sepsis, which is characterized by a reduced cellular oxygen extraction from the circulation. This phenomenon called "cytopathic hypoxia" is reflected in the relatively high venous oxygen level as compared to the arterial oxygen level and is likely due to mitochondrial dysfunction [51-53]. Mitochondrial dysfunction is an early and important event that may progress into loss of cellular homeostasis, organ failure, and ultimately death of the patient $[54,55]$. The induction of brief hyperoxemia, by increasing the $\mathrm{FiO}_{2}$ to 1.0 for 20 minutes in ventilated patients with severe sepsis and 
septic shock, paradoxically even decreases oxygen delivery in the upper limbs [47]. High central venous oxygen levels $\left(\mathrm{ScvO}_{2} ; 90-100 \%\right)$ are associated with increased mortality rates, as demonstrated in a prospective study comprising 619 septic patients treated with early goal-directed therapy in the ED [48]. It should be noted, however, that the $\mathrm{ScvO}_{2}$ during sepsis is not only influenced by the level of oxygen supplementation, but also by the occurrence of cytopathic hypoxia, which leads to a rise in $\mathrm{ScvO}_{2}$. Therefore, arterial oxygen levels better reflect the effect of oxygen supplementation in sepsis. High levels of oxygen supplementation (reflected by $\left.\mathrm{FiO}_{2}>60 \%\right)$ and also hypoxemia $\left(\mathrm{PaO}_{2}<8 \mathrm{kPa}\right)$ are associated with higher in-hospital mortality rates among 1,770 patients with severe sepsis or septic shock admitted to the ICU [49].

\section{Discussion}

Despite the longstanding and ubiquitous use of oxygen there is a paucity of data regarding its optimal use. Remarkably, guidelines describing the optimal dose of oxygen to be supplemented are scarce and current evidence is largely of low level, since it is largely based on observational cohort studies. There are only a few randomized prospective studies describing the effects of hyperoxemia on clinically relevant outcomes. Although we aimed to review the described effects of hyperoxemia on clinically relevant outcomes among acutely ill patients at the ED, most studies describe the effects of hyperoxemia after cardiac arrest, stroke, TBI, or sepsis among patients admitted to the ICU. However, since most patients presenting with these conditions will be primarily admitted to the ED before going to the ICU, we feel that these presented findings can also be applied to these specific ED populations. Yet it remains to be studied whether a similar association between hyperoxemia and clinically relevant outcomes (such as neurological or functional status and mortality) also applies to the patients at the ED that will not be admitted to the ICU. Investigating the potentially negative effects of hyperoxemia in this population may be of major clinical relevance, since oxygen treatment is mostly initiated in the ambulance and continued or started in the ED. There is the need for, preferably randomized, trials with well-defined outcome parameters, including neurological outcome, quality of life, and mortality, to achieve a higher level of evidence.

\section{Conclusion}

Despite the widespread and liberal use of oxygen supplementation in patients with acute illness, which is expected to lead to hyperoxemia in the majority of patients, studies describing the association between hyperoxemia and clinically relevant outcomes are scarce. Although a single study suggested transient improvement of clinical deficits after ischemic stroke treated with high oxygen supplementation, all other studies reviewed here revealed no positive association between hyperoxemia and outcome (such as neurological or functional recovery and mortality). Importantly, several studies described a clear association between hyperoxemia and increased mortality after cardiac arrest, stroke, and TBI. The association between hyperoxemia in sepsis and outcome remains to be studied. Despite these uncertainties, measuring blood oxygenation and aiming for normoxemia may potentially lower the morbidity and mortality associated with hyperoxemia. There is some support that the old paradigm by Paracelsus that toxicity only depends on dose is also true for the highly valued oxygen.

\author{
Abbreviations \\ CPR: Cardiopulmonary resuscitation \\ ED: Emergency department \\ ICU: Intensive care unit \\ MRI: Magnetic resonance imaging \\ NRM: Nonrebreathing mask \\ OHCA: Out-of-hospital cardiac arrest \\ $\mathrm{PaO}_{2}$ : Partial pressure of oxygen in arterial blood \\ ROS: Reactive oxygen species \\ ROSC: Return of spontaneous circulation \\ $\mathrm{ScvO}_{2}$ : Central venous oxygen saturation \\ STEMI: ST-segment elevation myocardial \\ infarction \\ TBI: $\quad$ Traumatic brain injury \\ VF: Ventricular fibrillation \\ VM: VentiMask.
}

\section{Additional Points}

Strengths of This Study. A comprehensive review about the association between hyperoxemia and clinically relevant outcomes in acutely ill adult patients. Limitations of This Study. Most reviewed studies are of a low level of evidence and mostly performed among patients admitted to the ICU, which does not cover the entire spectrum of emergency medicine.

\section{Conflicts of Interest}

None of the authors have conflicts of interest.

\section{Authors' Contributions}

All authors were involved in the design of the study. R. Stolmeijer and J. J. M. Ligtenberg performed the original literature search and wrote the first draft of this review. $\mathrm{H}$. R. Bouma, J. G. Zijlstra, A. M. Drost-de Klerck, and J. C. ter Maaten edited the manuscript.

\section{References}

[1] F. Sjöberg and M. Singer, "The medical use of oxygen: a time for critical reappraisal," Journal of Internal Medicine, vol. 274, no. 6, pp. 505-528, 2013.

[2] B. R. O'Driscoll, L. S. Howard, and A. G. Davison, "BTS guideline for emergency oxygen use in adult patients," Thorax, vol. 63, no. 6, pp. vil-vi68, 2008.

[3] British Thoracic Society. Guideline for emergency oxygen use in adult patients. Thorax 2008; 63: 1-68. 
[4] A. S. M. Dobbe, R. Stolmeijer, J. C. ter Maaten et al., Titration of oxygen therapy in critically ill emergency department patients: a feasibility study.

[5] G. M. Eastwood, A. Tanaka, E. D. V. Espinoza et al., "Conservative oxygen therapy in mechanically ventilated patients following cardiac arrest: a retrospective nested cohort study," Resuscitation, vol. 101, pp. 108-114, 2016.

[6] A. E. De Graaff, D. A. Dongelmans, J. M. Binnekade, and E. De Jonge, "Clinicians' response to hyperoxia in ventilated patients in a Dutch ICU depends on the level of $\mathrm{FiO}_{2}$," Intensive Care Medicine, vol. 37, no. 1, pp. 46-51, 2011.

[7] G. Eastwood, R. Bellomo, M. Bailey et al., "Arterial oxygen tension and mortality in mechanically ventilated patients," Intensive Care Medicine, vol. 38, no. 1, pp. 91-98, 2012.

[8] R. E. Moon, “Oxygen in acute illness: More or less?" Critical Care Medicine, vol. 43, no. 7, pp. 1547-1548, 2015.

[9] E. de Jonge, L. Peelen, P. J. Keijzers et al., "Association between administered oxygen, arterial partial oxygen pressure and mortality in mechanically ventilated intensive care unit patients," Critical Care, vol. 12, no. 6, article R156, 2008.

[10] P. Asfar, M. Singer, and P. Radermacher, "Understanding the benefits and harms of oxygen therapy," Intensive Care Medicine, vol. 41, no. 6, pp. 1118-1121, 2015.

[11] D. Trachootham, W. Lu, M. A. Ogasawara, N. R.-D. Valle, and P. Huang, "Redox regulation of cell survival," Antioxidants \& Redox Signaling, vol. 10, no. 8, pp. 1343-1374, 2008.

[12] M. L. H. Gruwel, C. Alves, and J. Schrader, "Na+-K+-ATPase in endothelial cell energetics: 23Na nuclear magnetic resonance and calorimetry study," American Journal of Physiology-Heart and Circulatory Physiology, vol. 268, no. 1, pp. H351-H358, 1995.

[13] D. F. S. Rolfe and G. C. Brown, "Cellular energy utilization and molecular origin of standard metabolic rate in mammals," Physiological Reviews, vol. 77, no. 3, pp. 731-758, 1997.

[14] P. W. Hochachka, "Defense strategies against hypoxia and hypothermia," Science, vol. 231, no. 4735, pp. 234-241, 1986.

[15] J. Santo-Domingo and N. Demaurex, "Calcium uptake mechanisms of mitochondria," Biochimica et Biophysica Acta (BBA) Bioenergetics, vol. 1797, no. 6-7, pp. 907-912, 2010.

[16] H. M. Honda, P. Korge, and J. N. Weiss, "Mitochondria and ischemia/reperfusion injury," Annals of the New York Academy of Sciences, vol. 1047, pp. 248-258, 2005.

[17] T. Akasaka, D. Lythall, A. Cheng et al., "Continuous aortic regurgitation in severely dysfunctional native hearts after heterotopic cardiac transplantation," American Journal of Cardiology, vol. 63, no. 20, pp. 1483-1488, 1989.

[18] Z. Bak, F. Sjöberg, and A. Rousseau, "Human cardiovascular dose-response to supplementary oxygen," Acta Physiologica, vol. 191, pp. 15-24, 2007.

[19] R. Stolmeijer, J. C. Ter Maaten, J. G. Zijlstra, and J. J. M. Ligtenberg, "Oxygen therapy for sepsis patients in the emergency department: a little less?" European Journal of Emergency Medicine, vol. 21, no. 3, pp. 233-235, 2014.

[20] A. M. Ranchord, R. Argyle, R. Beynon et al., "High-concentration versus titrated oxygen therapy in ST-elevation myocardial infarction: a pilot randomized controlled trial," American Heart Journal, vol. 163, no. 2, pp. 168-175, 2012.

[21] W. Spindelboeck, O. Schindler, A. Moser et al., "Increasing arterial oxygen partial pressure during cardiopulmonary resuscitation is associated with improved rates of hospital admission," Resuscitation, vol. 84, no. 6, pp. 770-775, 2013.
[22] J. Vaahersalo, S. Bendel, M. Reinikainen et al., "Arterial blood gas tensions after resuscitation from out-of-hospital cardiac arrest: Associations with long-term neurologic outcome," Critical Care Medicine, vol. 42, no. 6, pp. 1463-1470, 2014.

[23] J. F. Ihle, S. Bernard, M. J. Bailey, D. V. Pilcher, K. Smith, and C. D. Scheinkestel, "Hyperoxia in the intensive care unit and outcome after out-of-hospital ventricular fibrillation cardiac arrest," Critical Care and Resuscitation, vol. 15, no. 3, pp. 186190, 2013.

[24] H. J. Helmerhorst, M. Roos-Blom, D. J. van Westerloo, A. AbuHanna, N. F. de Keizer, and E. de Jonge, "Associations of arterial carbon dioxide and arterial oxygen concentrations with hospital mortality after resuscitation from cardiac arrest," Critical Care, vol. 19, no. 1, 2015.

[25] R. Bellomo, M. Bailey, G. M. Eastwood et al., "Arterial hyperoxia and in-hospital mortality after resuscitation from cardiac arrest," Critical Care, vol. 15, no. 2, article no. R90, 2011.

[26] M. Christ, K. I. von Auenmueller, M. Brand, S. Amirie, B. M. Sasko, and H.-J. Trappe, "Hyperoxia early after hospital admission in comatose patients with non-traumatic out-ofhospital cardiac arrest," Medical Science Monitor, vol. 22, pp. 3296-3300, 2016.

[27] B. K. Lee, K. W. Jeung, H. Y. Lee et al., "Association between mean arterial blood gas tension and outcome in cardiac arrest patients treated with therapeutic hypothermia," The American Journal of Emergency Medicine, vol. 32, no. 1, pp. 55-60, 2014.

[28] J. H. Kilgannon, A. E. Jones, N. I. Shapiro et al., "Association between arterial hyperoxia following resuscitation from cardiac arrest and in-hospital mortality," Journal of the American Medical Association, vol. 303, no. 21, pp. 2165-2171, 2010.

[29] J. Elmer, M. Scutella, R. Pullalarevu et al., "The association between hyperoxia and patient outcomes after cardiac arrest: analysis of a high-resolution database," Intensive Care Medicine, vol. 41, no. 1, pp. 49-57, 2015.

[30] J. H. Kilgannon, A. E. Jones, J. E. Parrillo et al., "Relationship between supranormal oxygen tension and outcome after resuscitation from cardiac arrest," Circulation, vol. 123, no. 23, pp. 2717-2722, 2011.

[31] D. R. Janz, R. D. Hollenbeck, J. S. Pollock, J. A. McPherson, and T. W. Rice, "Hyperoxia is associated with increased mortality in patients treated with mild therapeutic hypothermia after sudden cardiac arrest," Critical Care Medicine, vol. 40, no. 12, pp. 3135-3139, 2012.

[32] P. Young, M. Bailey, R. Bellomo et al., "HyperOxic Therapy OR NormOxic Therapy after out-of-hospital cardiac arrest (HOT OR NOT): a randomised controlled feasibility trial," Resuscitation, vol. 85, no. 12, pp. 1686-1691, 2014.

[33] P. Young, R. Beasley, M. Bailey et al., "The association between early arterial oxygenation and mortality in ventilated patients with acute ischaemic stroke," Critical Care Resuscitation, vol. 14, pp. 14-19, 2012.

[34] F. Rincon, J. Kang, M. Maltenfort et al., "Association between hyperoxia and mortality after stroke: a multicenter cohort study," Critical Care Medicine, vol. 42, no. 2, pp. 387-396, 2014.

[35] M. Lång, R. Raj, M. B. Skrifvars, M. Reinikainen, and S. Bendel, "In Reply: Early Moderate Hyperoxemia does not Predict Outcome After Aneurysmal Subarachnoid Hemorrhage," Neurosurgery, vol. 80, no. 5, pp. E253-E253, 2017.

[36] A. B. Singhal, T. Banner, L. Roccatagliata et al., "A pilot study of normobaric oxygen therapy in acute ischemic stroke," Stroke, vol. 36, no. 4, pp. 797-802, 2005. 
[37] M. V. Padma, A. Bhasin, R. Bhatia et al., "Normobaric oxygen therapy in acute ischemic stroke: A pilot study in Indian patients," Annals of Indian Academy of Neurology, vol. 13, no. 4, pp. 284-288, 2010.

[38] J. Nortje, J. P. Coles, I. Timofeev et al., "Effect of hyperoxia on regional oxygenation and metabolism after severe traumatic brain injury: Preliminary findings," Critical Care Medicine, vol. 36, no. 1, pp. 273-281, 2008.

[39] M. M. Tisdall, I. Tachtsidis, T. S. Leung, C. E. Elwell, and M. Smith, "Increase in cerebral aerobic metabolism by normobaric hyperoxia after traumatic brain injury," Journal of Neurosurgery, vol. 109, no. 3, pp. 424-432, 2008.

[40] A. Vilalta, J. Sahuquillo, M.-A. Merino et al., "Normobaric hyperoxia in traumatic brain injury: does brain metabolic state influence the response to hyperoxic challenge?" Journal of Neurotrauma, vol. 28, no. 7, pp. 1139-1148, 2011.

[41] M. N. Diringer, V. Aiyagari, A. R. Zazulia, T. O. Videen, and W. J. Powers, "Effect of hyperoxia on cerebral metabolic rate for oxygen measured using positron emission tomography in patients with acute severe head injury," Journal of Neurosurgery, vol. 106, no. 4, pp. 526-529, 2007.

[42] A. M. Puccio, L. A. Hoffman, H. Bayir et al., "Effect of short periods of normobaric hyperoxia on local brain tissue oxygenation and cerebrospinal fluid oxidative stress markers in severe traumatic brain injury," Journal of Neurotrauma, vol. 26, no. 8, pp. 1241-1249, 2009.

[43] D. P. Davis, W. Meade Jr., M. J. Sise et al., "Both hypoxemia and extreme hyperoxemia may be detrimental in patients with severe traumatic brain injury," Journal of Neurotrauma, vol. 26, no. 12, pp. 2217-2223, 2009.

[44] F. Rincon, J. Kang, M. Vibbert, J. Urtecho, M. K. Athar, and J. Jallo, "Significance of arterial hyperoxia and relationship with case fatality in traumatic brain injury: a multicentre cohort study," Journal of Neurology, Neurosurgery \& Psychiatry, vol. 85, no. 7, pp. 799-805, 2014.

[45] S. R. Asher, P. Curry, D. Sharma et al., "Survival advantage and $\mathrm{PaO} 2$ threshold in severe traumatic brain injury," Journal of Neurosurgical Anesthesiology, vol. 25, no. 2, pp. 168-173, 2013.

[46] R. Raj, S. Bendel, M. Reinikainen et al., "Hyperoxemia and longterm outcome after traumatic brain injury," Critical Care, vol. 17, no. 4, article no. R177, 2013.

[47] P. Rossi, L. Tauzin, M. Weiss, J.-C. Rostain, J.-M. Sainty, and A. Boussuges, "Could hyperoxic ventilation impair oxygen delivery in septic patients?" Clinical Physiology and Functional Imaging, vol. 27, no. 3, pp. 180-184, 2007.

[48] J. V. Pope, A. E. Jones, D. F. Gaieski, R. C. Arnold, S. Trzeciak, and N. I. Shapiro, "Multicenter Study of Central Venous Oxygen Saturation $(\mathrm{ScvO} 2)$ as a Predictor of Mortality in Patients With Sepsis," Annals of Emergency Medicine, vol. 55, no. 1, pp. 40-e1, 2010.

[49] R. M. Dahl, L. Grønlykke, N. Haase et al., "Variability in targeted arterial oxygenation levels in patients with severe sepsis or septic shock," Acta Anaesthesiologica Scandinavica, vol. 59, no. 7, pp. 859-869, 2015.

[50] M. Girardis, S. Busani, E. Damiani et al., "Effect of conservative vs conventional oxygen therapy on mortality among patients in an intensive care unit: the Oxygen-ICU randomized clinical trial," The Journal of the American Medical Association, vol. 316, no. 15, pp. 1583-1589, 2016.

[51] M. P. Fink, "Cytopathic hypoxia in sepsis: a true problem?" Minerva Anestesiologica, vol. 67, no. 4, pp. 290-291, 2001.
[52] M. A. Hayes, A. C. Timmins, E. H. S. Yau, M. Palazzo, D. Watson, and C. J. Hinds, "Oxygen transport patterns in patients with sepsis syndrome or septic shock: influence of treatment and relationship to outcome," Critical Care Medicine, vol. 25, no. 6, pp. 926-936, 1997.

[53] M. Rocha, R. Herance, S. Rovira, A. Hernández-Mijares, and V. M. Víctor, "Mitochondrial dysfunction and antioxidant therapy in sepsis," Infectious Disorders - Drug Targets, vol. 12, no. 2, pp. 161-178, 2012.

[54] D. Brealey, M. Brand, I. Hargreaves et al., "Association between mitochondrial dysfunction and severity and outcome of septic shock," The Lancet, vol. 360, no. 9328, pp. 219-223, 2002.

[55] M. Singer, "The role of mitochondrial dysfunction in sepsisinduced multi-organ failure," Virulence, vol. 5, no. 1, pp. 66-72, 2014. 


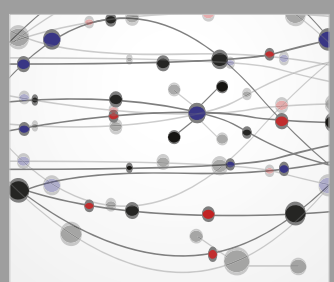

The Scientific World Journal
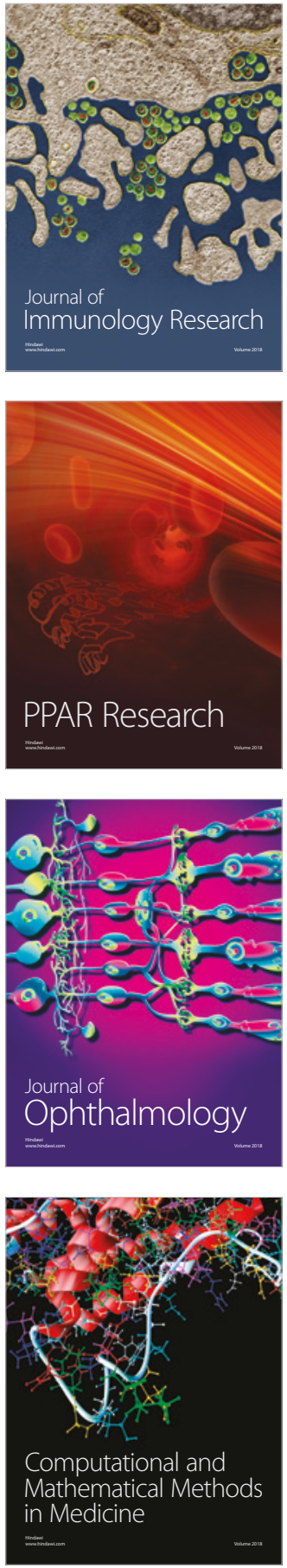

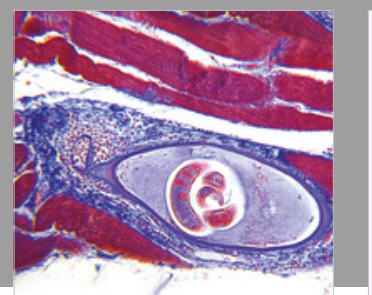

Gastroenterology Research and Practice

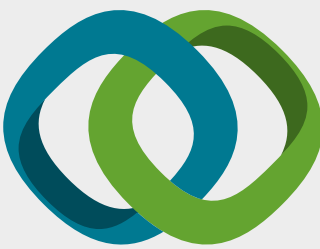

\section{Hindawi}

Submit your manuscripts at

www.hindawi.com
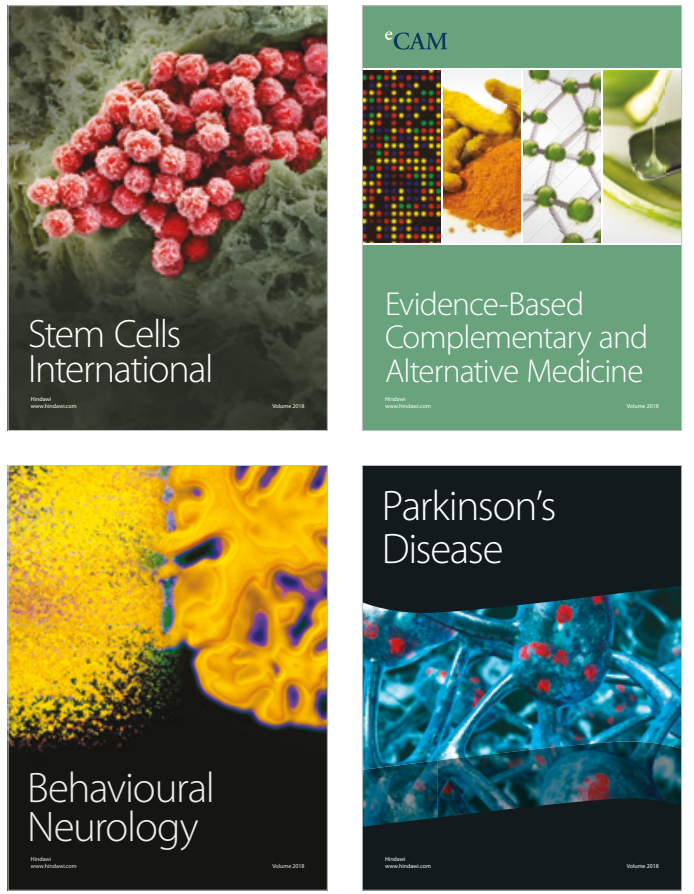

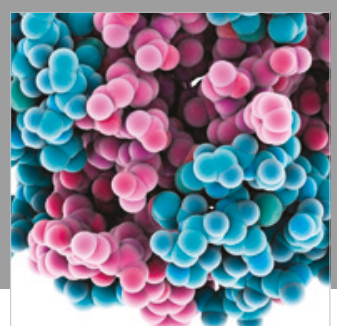

ournal of

Diabetes Research

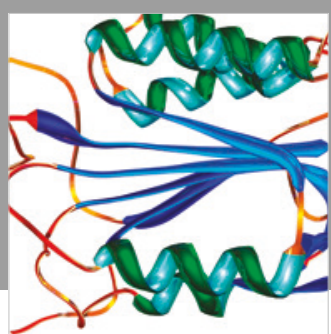

Disease Markers
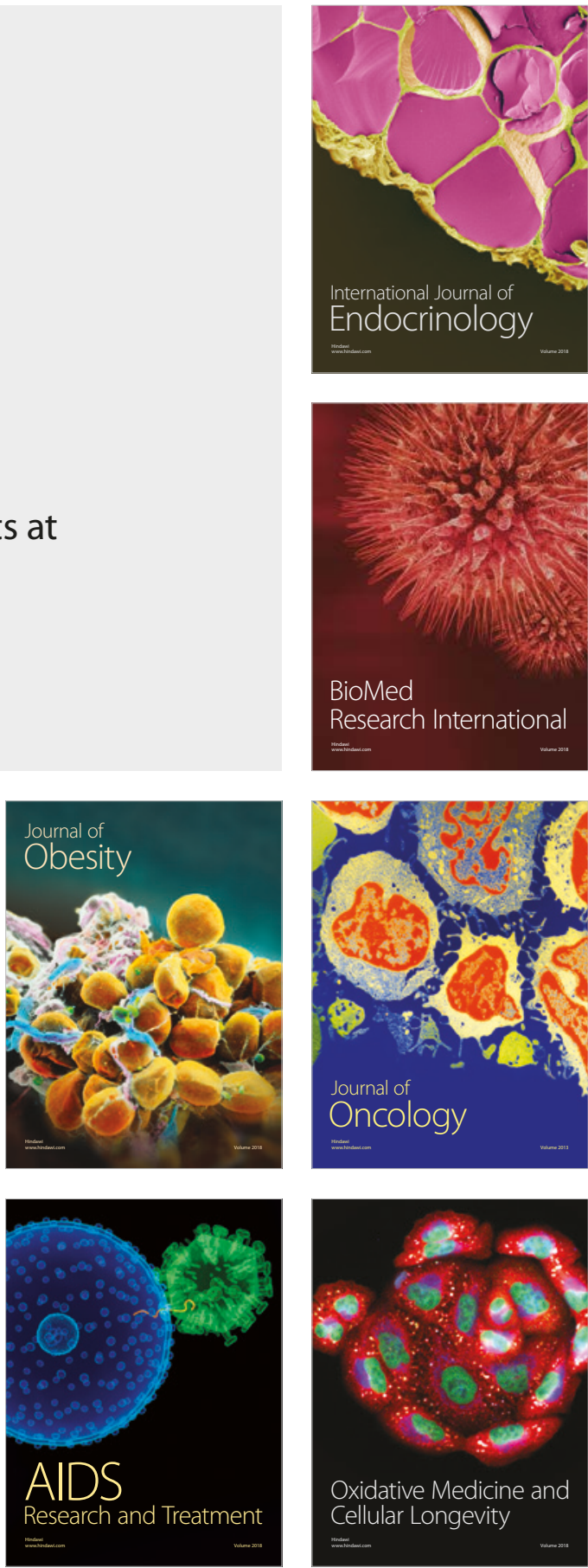